\title{
Strategies of Community Empowerment to Manage Protection Forest Sustainably
}

\author{
Fitta Setiajiati $^{1^{*}}$, Hardjanto ${ }^{2}$, Hendrayanto ${ }^{2}$ \\ ${ }^{1}$ Graduated School of Bogor Agricultural University, Campus IPB Dramaga, Bogor, Indonesia 16680 \\ ${ }^{2}$ Department of Forest Management, Faculty of Forestry, Bogor Agricultural University, \\ Academic Ring Road, Campus IPB Dramaga, PO Box 168, Bogor, Indonesia 16680
}

Received April 7, 2017/Accepted August 11, 2017

\begin{abstract}
The Indonesian Government has empowered communities that are living adjacent to forests, but at the same time, protection forests are highly encroached by local community. In response, our study aims at formulating strategies of community empowerment in protection forest management. Data collection through participatory observation, questionnaire surveys, interviews, and focused group discussions were conducted in the surrounding communities of protection forest areas in Sumbawa District, Indonesia. A combination of descriptive, participatory, and explorative approaches were used for data analysis. The knowledge of local communities on protection forest conservation was found to be on an average level, while their attitudes towards conservation was assessed as being on a higher level. Community empowerment programs implemented by the government were shown to have no significant effect on knowledge improvement, but they were more effective in changing the community's attitudes regarding protection forest management. Local communities were shown to be willing to conduct conservation activities as well as looking for cash income. Therefore, our study suggested that community empowerment programs should link forest conservation with income opportunities for local people, such as implementing conservation agriculture (e.g. agroforestry), partnerships in the production and sale of non-timber forest products, and conducting clearly reward and punishment for communities.
\end{abstract}

Keywords: community empowerment, protection forests, conservation, knowledge, attitude

*Correspondenceauthor,email:fittsjiati@gmail.com

\section{Introduction}

The Indonesian Government divides types of forests based on function; these are production forest, protection forest, and conservation forest. The main function of production forest is to product timber, conservation forest is to conserve wildlife and biodiversity, and protection forest is to protect hydrological function and encourage water and soil conservation (The Law of the Republic of Indonesia Number 41 Year 1999 concerning Forestry). Protection forest is designated based on soil vulnerability to run-off and erosion through considering the characters of soil types, slope, elevation, and rainfall. Protection forests require land use systems which can reduce run-off and erosion until the secure rate to achieve the main function is reached. However, forest encroachment and deforestation occur in protection forest area (FWI 2014). An important reason of forest encroachment is the high dependency of local community on forests. They are often among the poorest communities in Indonesia (Wollenberg et al. 2004 cited by Mutaqin 2014). Their livelihoods depend on the forest resources, and their access to land is limited. In line to people growth development, the needs on food and energy have increased as well as the need on land resources which can threat forest land (Brockhaus et al. 2012).
The biophysical characteristics of protection forest and their ecological functions are vulnerable to land use changes, such as deforestation, which may decrease in a loss of watershed functions, increase run-off, erosion, sedimentation, and floods. The land use change can be caused by natural and/or human activities. Communities living within the vicinity of the protection forest were reputed as challenging situation to the conservation efforts (Ostrom 1999), that they were also reputed as causing a loss of watershed functions by government agencies (Verbist $e t$ al. 2005).

In general, human activities conducted in protection forest can have positive or negative effects for protection forest conservation. Communities can contribute to protection forest conservation through their indigenous knowledge in enforcing customary law, but can also treat the existing forest due to over exploitation (Sukardi et al. 2008). Therefore, the interactions between communities and their surrounding forests need to be optimized to achieve social, economic, and ecological benefits. Unfortunately, most of the protection forest areas in Indonesia have not been wellmanaged (Mutaqin 2014). Moreover, forest policy related to protection forest has had many problems such as overlapping and conflicting forest policies, unclear terminologies, and 
disharmony of forest policies (Ginoga et al. 2005; Dunggio 2012; Ekawati et al. 2012).

In response to deforestation and forest degradation, the Government Regulation Number 6/2007 juncto Number 3/2008 regarding Forest Arrangement and Formulation of Forest Management Plan as well as Forest Exploitation aims at dividing the entire forest areas into Forest Management Units (FMUs) in order to govern and maintain them in a sustainable way. As new institutions, FMUs face many challenges. Sumbawa District, for instance, has three FMUs, which experience similar problems, such as illegal logging and forest encroachment for agriculture. Among the three FMUs is the FMU of Batulanteh, which was established in 2011.

There is an urgent need to establish new approaches of sustainable forest management, which includes more community participation (Darusman et al. 2013). Forest communities are supposed to be key stakeholders in protection forest management because their livelihoods depend on the protection forest (Ekawati 2012). However, participatory approaches in rural development have often resulted in manipulating local populations and imposing outside agendas rather than local empowerment (Edmunds \& Wollenberg 2003). Agencies persists with top-down approaches in community development projects (Evans et al. 2010). The goals and outcomes of activities are often determined by external stakeholders such as policymakers, scientists, and donors, while local people's points of views are often neglected (Schusser 2013) and local realities disregarded (Hoch et al. 2009). Most forest planning has been designed based on the needs and concerns of governments and companies without carefully considering and consulting the needs of local communities. The local communities did not have power to influence the process of establishing, executing and monitoring the plans. Therefore, the involvement of local communities in the forest management was historically very low (Purnomo 2005).

Communities are important actors in natural resources management (Agrawal 2003) and can be the most effective stewards in forest management when they are given an opportunity in decision making (Colfer 2005). Participation of local community has been shown to be a major factor in the success or failure of natural resource protection (Du Toit 2002). Therefore, community empowerment is needed for improving community participation. Community empowerment can also minimize social conflicts and maximize equity of benefit sharing (Ostrom et al. 1999).

The Law of the Republic of Indonesia Number 41 Year 1999 concerning Forestry instructs that forest resources are managed and used for the greatest prosperity of the people while conserving the environment. Furthermore, in the Government Regulation Number 6/2007, in the Eleventh Part, the local community empowerment is defined. As for instance in the Article 83, which regulates that the local community empowerment is (1) in order to obtain benefits of forest resources optimally and fairly, and (2) an obligation, which has to be promoted by the government, province, and municipal in which the head of the FMUs have the responsibility for its implementation. In response to this mandate, FMUs have already conducted community empowerment, including in the FMU of Batulanteh. In fact, FMU of Batulanteh has already put many efforts to reduce forest encroachment, yet encroachment is still occurs.

Ideally, community empowerment should be designed in a way that is compatible with the need, ability, desire, and behavior of the community people. That is why understanding local community knowledge and attitudes on protection forest conservation and the sustainable management of natural resources is crucial (Triguero-Mas et al. 2010). The studies of local community attitudes have also contributed to a better understanding of local people needs and aspirations for conservation (Infield \& Namara 2001). Therefore, this study aims to develop community empowerment strategies using bottom-up approaches that consider local community knowledge, attitudes, needs, wishes, and behaviors. Our study also wants accommodate community forestry initiatives in a way that promote local empowerment and avoid dysfunction as a result of using topdown approaches. In specific, our study wants to (1) analyze the knowledge and attitude of local community on protection forest conservation, (2) evaluate FMU's community empowerment programs, and (3) formulate the strategies of community empowerment program.

\section{Methods}

Study site The study was undertaken in the surrounding protection forest area of Sumbawa District, West Nusa Tenggara Province, Indonesia, which is managed by the FMU of Batulanteh. The area includes 25 villages distributed in eight sub-districts. Each village consists of 3-4 subvillages. The population is composed by indigenous people of Sumbawa, and some migrants from Lombok, Bali, Bima, and Java. The total population is 50,333 people (male: 24,605 people; female: 25,728 people) of 1,305 households and the main occupations are farmers, fishermen, and breeders (Pusrenbang 2016). Forestry Multi-Stakeholders Team (Tim Multistakeholder Kehutanan) stated that about $80 \%$ of local community surrounding Sumbawa forest area is classified as a poor people (Supardi et al. 2006). The dependency of local community on protection forest was relatively high that contributed $33 \%$ for cash income and supported food security (Setiajiati et al. 2017).

Seven sub-villages named Batudulang, Punik, Pusu, Semamung, Sempe Atas, Sempe Bawah, and Brangrea Luar were in the focus of our study. The sites were selected by purposive sampling, as representative villages which have special case. These sub-villages had high interaction between community and forest area based on rapid appraisal and preliminary survey. Table 1 shows the reasons of subvillage selection and Figure 1 shows the location of each subvillage.

Data collection and analysis A mixed method approach was used for data collection. Data and information were gathered through a range of in-depth qualitative explorations followed by incorporating the results into a questionnaire. The first phase of data collection was conducted between August and November 2015 and consisted of preliminary surveys, community and forest observations, semi-structured interviews, and focused group discussion (FGD). The second 


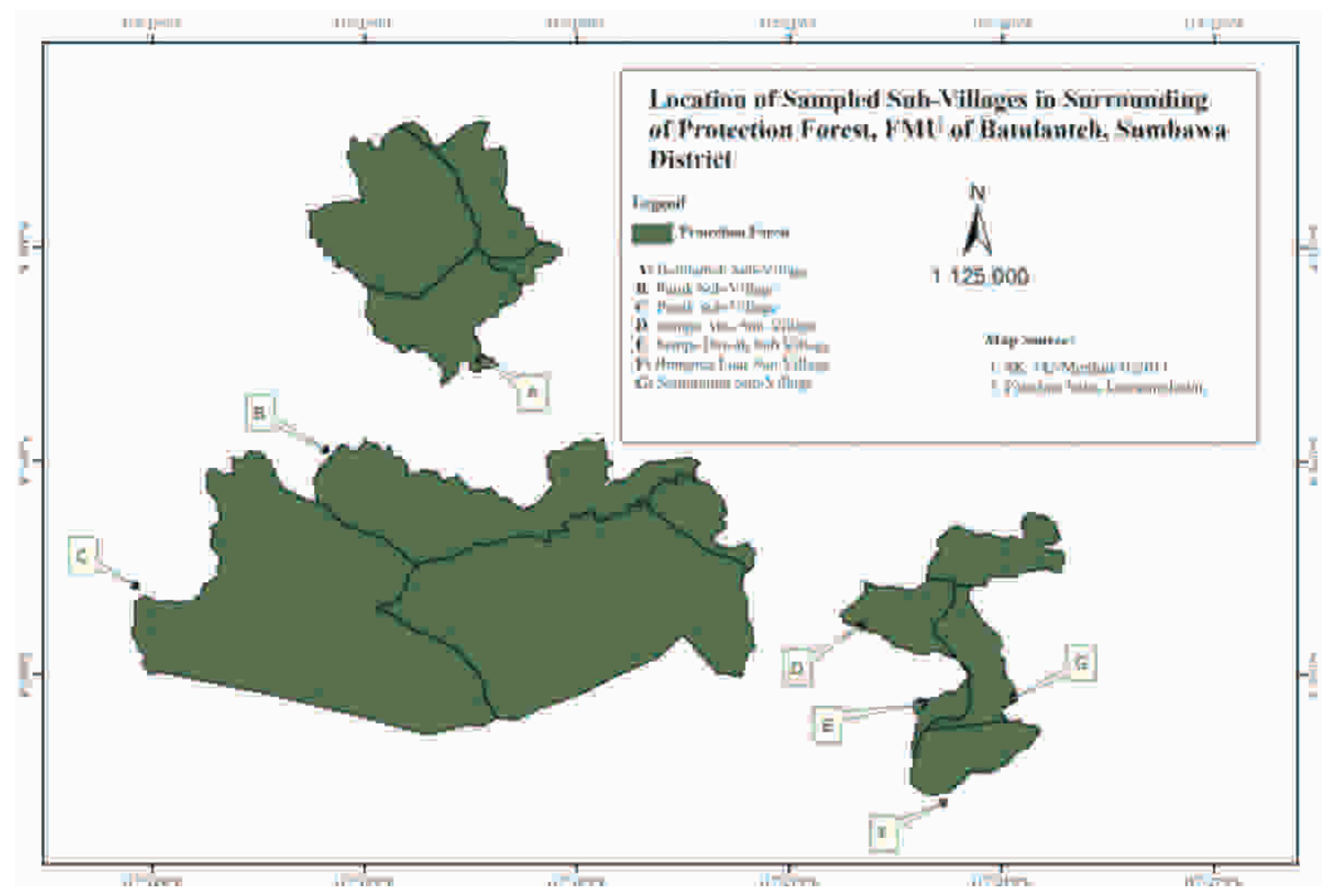

Figure 1 The distribution of study sites.

Table 1 Sub-villages communities and their relationships with protection forests

\begin{tabular}{|c|c|}
\hline Sub-village & Community and protection forest relationship \\
\hline Batudulang & High dependency on forests regarding wild honey harvesting \\
\hline Punik & Community have large coffee plantations in FMU's forest areas, especially in protection forests \\
\hline Pusu & $\begin{array}{l}\text { Representative of other sub -villages which have not received community empowerment programs from } \\
\text { the FMU and had no special issues }\end{array}$ \\
\hline Sempe Atas & $\begin{array}{l}\text { Community collected Usnea barbata by cutting the trees in protection forest and neglected the trees, just } \\
\text { took U. barbata. U. barbata is a genus from Parmeliaceae family for medicine, cosmetics, etc. } \\
\text { Cutting the trees in protection forests is totally prohibited }\end{array}$ \\
\hline Sempe Bawah & $\begin{array}{l}\text { Community collected } U \text {. barbata by cutting the trees in protection forest and neglected the trees, just } \\
\text { took } U \text {. barbata. Cutting the trees in protection forests is totally prohibited }\end{array}$ \\
\hline Brangrea Luar & $\begin{array}{l}\text { Representative of other sub-villages which have not received community empowerment programs from } \\
\text { the FMU and had no special issues }\end{array}$ \\
\hline Semamung & $\begin{array}{l}\text { This sub-village which had high rate in illegal logging cases for business based on information of FMU } \\
\text { staffs }\end{array}$ \\
\hline
\end{tabular}

phase was a questionnaire survey conducted from January to November 2016. Afterwards, the data was analyzed by using descriptive analysis in quantitative and qualitative ways. In the questionnaire survey, the questions were adopted from Budiono (2009) and adapted to the local conditions to explore the knowledge and attitudes of local community on protection forest conservation. The questions were related to the skills and knowledge about forest conservation and management, including forest functions, tree nursery management, forest maintenance, forest harvesting, forest business, forest policy, and community participation. The questions regarding attitudes were related to local community views on social interaction, forest business and utilization, and activities in the forests. The questionnaires were allotted for 193 households in seven sub-villages. The family head was selected as household representative because they often visit forest area to meet family subsistence needs. All household representatives were male, farmers, and indigenous to East Nusa Tenggara Province, mostly educated at low level of formal education and in productive ages (Figure 2).

The semi-structured interviews were conducted to obtain 


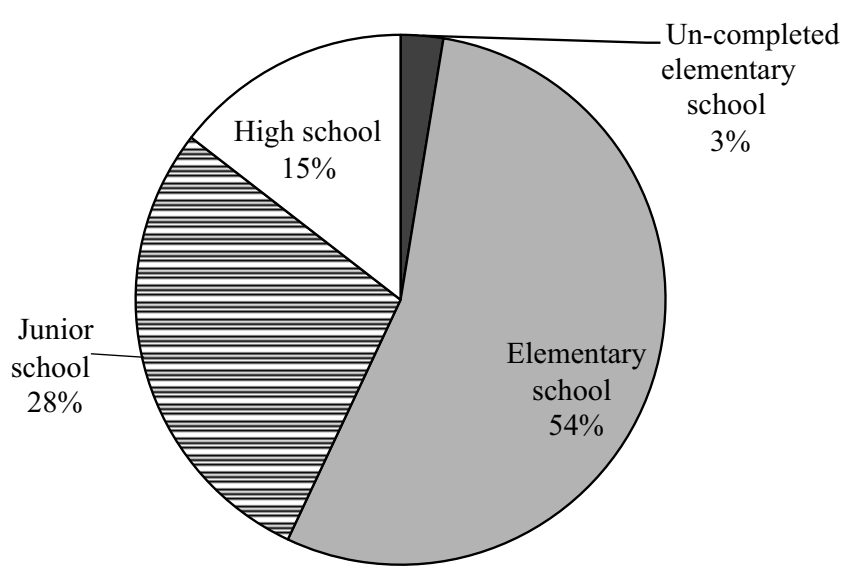

(a)

Figure 2 Profile of respondents: age (a), and education (b).

data of 45 households with high interests and interactions with forests, the ability to express their perceptions and opinions and presumable knowledge about community empowerment based on observation in questionnaire survey. Open-ended interviews with 45 households were designed to get information related to community perception and participation on forest protection, and ideas on how to empower communities effectively.

FGDs were held two times. The first FGD was held in September 2015 and attended by 37 participants, consisting of FMU staffs, government agencies, business/ private actors, and local community people. The main topic was about the general problems in the FMU of Batulanteh and its solutions in order to gain in-depth experiential accounts of different actor's perceptions and concerns in FMU of Batulanteh governance. The second FGD was conducted in October 2015 with 10 community people in Batulanteh Village. The main goal was to gain their views, opinions, and ideas related to protection forest conservation.

A combination of descriptive-participative-explorative approaches were used for data analysis. A Likert scale was used to analyze the knowledge and attitude for forest protection by questionnaire surveys which categorized scores into five classes. The questionnaire related to knowledge on protection forest conservation consisted of 50 questions with multiple answer choice. The households needed to answer correctly based on general knowledge of environment management. The amount of true answers showed community competency of knowledge on protection forest conservation, which was consisted five categories: excellent (40-50), good (30-39), average (20-29), below average (10-19), and bad (0-9). Category of excellent was meant that community has already understood about theory, concept, techniques, and practice of protection forest conservation, especially about forest functions, tree nursery management, forest maintenance, forest harvesting, forest business, forest policy, and community participation. So, category of good, average, below average, and bad was meant that understanding of theory, concept, techniques, and practice of protection forest conservation was not completed yet. The questionnaire related to attitudes consisted of 49 statements with two response choices to state agreement and

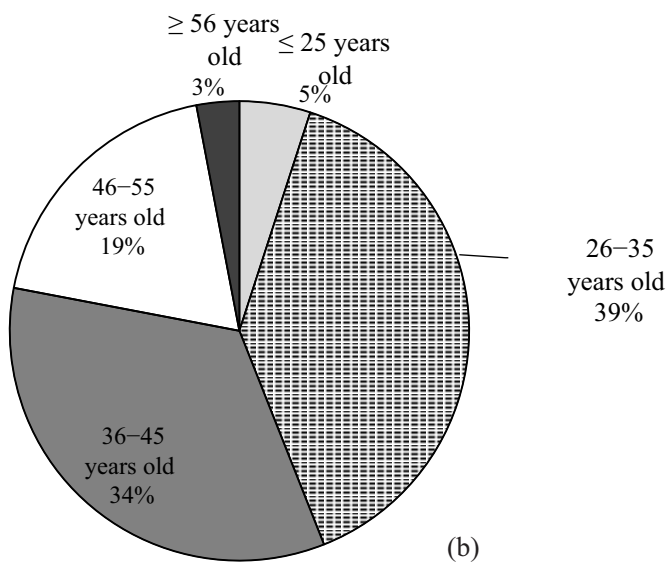

disagreement: True answers of attitude questions were based on ideally perception of theoretical concepts and it was calculated to find category each household: excellent (40-49), good (30-39), average (20-29), below average (10-19), and bad (0-9). Excellent attitudes was meant that community people had good mindset related to forest conservation (especially about views on social interaction, forest business and utilization, and activities in the forests), as well as keeping harmonization among natural, social, and economic interest. So, category of good, average, below average, and bad in attitudes was meant that their mindset need to be improved due to something wrong of perception on forest conservation. Community empowerment strategies were formulated by a synthesis among the results of field observation, questionnaire survey, semi-structured interviews, open-ended interviews, and FGDs in descriptive analysis.

\section{Results and Discussion}

Knowledge and attitudes of local community on protection forest conservation Overall, the knowledge of respondents on protection forest conservation was in average level based on the result of questionnaire survey (Table 2). The knowledge towards protection forest conservation is related to forest function, nursery and planting skill, forest maintenance, forest business, forest policy, and community participation which was described as followed:

\section{Forest function}

Basic ecological knowledge of communities was limited. Communities could not understand about relationship of forest, water, soil or hydrological system, although they noticed that the forest provides intangible environmental services, such as water supply and controlling the climate. However, community people always mentioned tangible benefits of forests (e.g. wild honey, wood, food) as priority of forest function rather than intangible benefit because they needed tangible things for supporting economic and cash income.

2 Nursery and planting skill

Community members have already understood how to make seedling, nursery, and soil fertilizing. However, 
Table 2 Knowledge and attitudes of forest community on protection forest conservation

\begin{tabular}{lcclcrl}
\hline \multirow{2}{*}{ Sub-village } & \multicolumn{3}{c}{ Knowledge } & \multicolumn{3}{c}{ Attitude } \\
\cline { 2 - 7 } & $\begin{array}{l}\text { Total of } \\
\text { respondents }\end{array}$ & $\begin{array}{l}\text { Average of } \\
\text { score }\end{array}$ & Category & $\begin{array}{c}\text { Total of } \\
\text { respondents }\end{array}$ & $\begin{array}{c}\text { Average of } \\
\text { score }\end{array}$ & Category \\
\hline Batudulang & 22 & 23.1 & Average & 22 & 31.8 & Good \\
Punik & 23 & 24.3 & Average & 22 & 32.9 & Good \\
Pusu & 30 & 24.3 & Average & 30 & 30.1 & Good \\
Sempe Atas & 30 & 25.9 & Average & 30 & 27.6 & Average \\
Sempe Bawah & 30 & 27.5 & Average & 30 & 28.4 & Average \\
Semamung & 28 & 26.3 & Average & 29 & 32.4 & Good \\
Brangrea Luar & 30 & 25.9 & Average & 30 & 30.1 & Good \\
& Total: 193 & 25.3 & Moderate & Total: 193 & 30.5 & Good \\
\hline
\end{tabular}

Note: knowledge score $=$ excellent $(40-50)$, good (30-39), average (20-29), below average (10-19), and bad (0-9). Attitude score $=$ excellent (40-49), good (30-39), average (20-29), below average (10-19), and bad (0-9).

their knowledge to conserve water and soil was poor. They practices slash and burn for opening forest as planting preparation in indigenous way. Community admitted that it was difficult to open forest without burning due to lack of investment and human resources. Furthermore, slash and burning is local tradition for opening forest in cheap way.

3 Forest maintenance

Community members have already understood which trees are susceptible to attack by pests and diseases, but they depended on chemical control of pests and diseases. Some community members neglected pest and disease damage to their plantation due to lack of income to invest in protection.

\section{Forest business}

Community people lacked business management skills to manage forest products. They sold products such as coffee beans, candle nut, medical plant in raw materials to middlemen. Generally, middlemen controlled prices, so farmers' bargaining position was weak. Middlemen were from both inside and outside of village and sometime gave loans to community people, so they agreed to sell their farming products to middlemen.

\section{Forest policy}

Knowledge of local communities regarding forest policy was lack. Community people have noticed that FMU of Batulanteh is government institution for forest management in Sumbawa District. However they did not well understand about location of protection and production forest in FMU of Batulanteh as well as the meaning and objectives of forest types (conservation forest, protection forest, and production forest) although they were familiar with these terminologies. Plenty of border signs were provided for clear information of forest types and boundaries, but communities could not understand. FMU staffs and other institutions have not socialized yet about forest type in Indonesia to local communities.

\section{Community participation}

Community participation was dependent on activities of forestry institutions, both government and nongovernment institutions. Generally, communities will be active if there were forestry activities in their area. Therefore, role of government and other institution was important to stimulate community participation.

Generally, communities had good attitudes towards protection forest conservation although the character of sub-villages was different as shown in Table 2. The community attitudes were related to social interaction, forest business and utilization, community activities in forest which were followed:

7 Social interaction

Generally, all communities could manage social interaction well. Community people gathered together with family and their neighbors on Friday as their day-off from farming and other activities and the day for praying together in the mosque. Besides that, they helped each other in arranging special events such as wedding party, baby-birth party by collecting money and manpower to prepare and manage the event. Although jealousy among people did exist, serious conflicts were rare in communities.

8 Forest business and utilization

Generally, community people had good attitudes and felt optimist to conduct sustainable forest business and utilization, although they realized their weaknesses in marketing. Community people of Batudulang, Punik, and Semamung tended to conserve forest to sustain forest honey that they would refuse forest conversion in their area. Furthermore, forest monitoring was often conducted by FMU staff in there, so eventually community people's knowledge has increased and it influenced their attitude on forest conservation such as realizing that logging and forest opening are illegal activities, although some people from Batudulang and Punik conducted forest clearing for establishing coffee plantations and some people from Semamung cut trees illegally for business due to economic reason. This condition was different with community people of Sempe Atas and Sempe Bawah that some people conducted 
illegal activities without feeling guilty. Sempe Atas and Sempe Bawah communities were being issues as illegal logger for collecting tree lichen (Usnea barbata) by cutting the trees and neglected the fall trees. The tree lichen would be sold to middlemen and will be used as cosmetic materials, herbal medicine, and decoration.

9 Community activities in forest

Community had large farming area which was located in surrounding of forest. They passed protection forest area as shorter way to go to their farming land. In the way of forest, they observed and looked for tangible potencies of forest, such as timber and non timber forest product. The collection of non-timber forest products (NTFPs) collection, such as wild honey, mushroom, rattan, coffee, and candle nuts, was the most frequent activity in the protection forest areas mentioned by the households. Generally, wild honey, coffee, and candle nuts were sold to improve their cash income, while rattan and mushrooms were used for their own consumption (Setiajiati et al. 2018). Community people also conducted illegal activities, such as logging for timber and $U$. barbata and clearing forests for coffee plantations and agricultural activities.

Based on the questionnaire survey and interview result, formal education of respondents did not influence their knowledge and attitude towards protection forest conservation. Through this study, we explored and found that non-formal education (e.g. training and forestry extension programs) influenced more on knowledge and attitudes than formal education. It showed that community empowerment was really essential and needed to develop community capacities. The age of respondents also did not influence knowledge and attitude on protection forest conservation. Some old people well understood about forest management, but other old people were not. Several young people also had good knowledge and attitudes of forest management, but the others were not. This is contrary to the results from Ansong and Roskaft (2011) and Ratsimbazafy et al. (2012) who stated that older people were more likely to hold favorable attitude towards conservation. Several respondents who get cash income highly had better attitudes on protection forest. This is in line with other studies from Badola et al. (2012) and Infield and Namara (2001) which showed that local communities will hold positive attitudes towards forest management and conservation if they received many benefits from forest.

Evaluation of FMU's community empowerment program Community empowerment has been conducted by FMU of Batulanteh in several sub-villages surrounding FMU of Batulanteh. Several FMU staff have communicated with community and educated young villagers to participate in forest conservation. However, activities of community empowerment and extension service were not equally distributed among the villages because the FMU of Batulanteh focused on several areas such as Batudulang, Punik, Semamung Sub-Village only. Besides, community empowerment was not conducted in a regular way.

Because of experiencing trainings, forestry extension, and FMU's programs, some Batudulang people came up with negative perception that FMU and government seems highly suspicious on their existence because of over monitoring and warning about illegal logging and land encroachment. In contrast, other sub-villages did not have attention as much as FMU treated to Batudulang sub-village. Sampe Atas, Sempe Bawah, Pusu, and Brangrea Luar sub-village had no training or community empowerment program at all, so several its community did not know about FMU existing. Although Batudulang sub-village got community empowerment programs more than others, local community knowledge on protection forest conservation was the same like others (Table 2). Community gained incomplete information from guidance leading to misunderstanding of perception on forest. This is probably because of inaccurate and weak delivery during incomplete and irregular program. It showed that community empowerment program has not influenced knowledge improvement. However, the program influenced changing attitudes of communities, in which Batudulang, Punik, and Semamung communities had more positive attitude than other communities (Table 2). Communities of Batudulang, Punik, Semamung have understood the illegal activities in the forest and participated in forest monitoring and conservation, although some people conducted illegal activities due to economic reason.

There was a huge gap of knowledge among individuals within their community. Several people had high knowledge and experience about forest and agriculture, but the others did not. It showed that information transferring did not occur among community people and individuals. The high knowledge and experience was not been influenced by age, gender, and educational level, but the activeness of individuals in forestry program influenced the improvement of knowledge and experience. Local community also admitted that they did not well understand during forestry extension process. Since information transferring seems to be one way, it was really difficult to get feedback from the communities. Consequently, there is no way to assess the effectiveness of forestry extension. Furthermore, door to door system of forestry extension was conducted in Batudulang and Semamung, again, this process did not spread equally for each households. Several respondents complained unequal empowerment because of personal interests of FMU personals such as business and friendship relationship between FMU staff and some local people. This information could be notes for FMU of Batulanteh to improve performance of staffs and its management.

Staffs of FMU of Batulanteh stated that the limited FMU staffs were one of the factors which caused unequally community empowerment program. The total number of FMU staff was 31 , which seems to be limited to manage a forest area of 32,776 ha in interaction with the local communities. Overall, although community empowerment program was not effective yet, most local community admitted that existing of FMU of Batulanteh was better for their capability and forest conservation than before. In general, the local communities appreciated the training and forestry extension from FMU of Batulanteh.

Strategies of community empowerment program Empowerment is constructing a link individual strength and competency, natural serving structure, and proactive behaviour for either social policy or social change 
(Rappaport 1984 cited by Perkins 1995). The concept of the empowerment program has to be designed in balance between community resources and its program objective as sustainable development (Arifudin et al. 2013).

All communities requested that community empowerment program needed to be conducted in regular schedule, starting from basic aspects of ecological knowledge. The schedule may follow community agenda. Community has weekly gathering agenda, such as gathering for prayer on Friday where community empowerment program could take place. During gathering in Mosque, villager representative sometimes announced important massage and continued with community empowerment program. It is rather effective and well addressed because the number of participant were higher than unscheduled guidance. Basic knowledge is necessary, and gaining comprehensive explanation is likely more sophisticated for them.

FMU staffs need to release personal interest in community empowerment. All sub-villages surrounding protection forests have the right to receive community empowerment program. As a starting point, FMU staffs need to visit all sub-villages and introduce existing of FMU of Batulanteh to show that protection forest is not public goods. FMU can open internship opportunity for college students to help community empowerment regarding FMU introduction. Sumbawa District has several universities which need internship program for building students capacity. It will be good cooperation between FMU of Batulanteh and academics for empowering local community and other activities. Non-government organizations (NGOs) and environmental voluntary groups in Sumbawa can also be requested to join in community empowerment program.

Generally, local community had willing to conserve protection forest, but they needed cash income for subsistence. They were not experienced and lack of knowledge to get more income while also conserving forest. This condition was more likely "to know, willing but unable to carry out" the sustainability (Budiono 2006) due to economic needs and lack of empowerment. Economic factors were always mentioned by all respondents as important, as they have low income. They need activities which can support the households' income. This might be instrumental for sustaining forest conservation. Based on this information, programs of community empowerment can be prioritized on economy aspects, conservation agriculture, and illegal activities prevention, as following:

\section{Economy aspects}

FMU of Batulanteh can improve community economic welfare by giving job opportunities to involve in FMU activities. FMU of Batulanteh has involved local community in several activities such as collecting research data and boundaries monitoring. However, these activities were only momentary, not continuously. FMU of Batulanteh needs to provide opportunity to make sustainably cooperation with local community, such as building nursery, one of results in FGD. Every year in wet season, forest rehabilitation and enrichment always be conducted by FMU of Batulanteh and other institutions related to environment protection. Nursery business can be conducted continuously every year to support land rehabilitation and plantation enrichment program.

FMU of Batulanteh needs human resource with high both in quality and quantity due to the limited staffs for referred to the large concession. In staff recruitment, local community should be the main priority and several local candidates could be potential recruited. By recruiting local community as staff, the process of information transfer would be more effective and the sense of belonging would be appeared. By field observation during four months in Sumbawa District, potentially local communities were available in Sumbawa District as well as in community living adjacent to the forests. Local community also stated that they wanted to contribute in protection forest management in authorized forestry institution, it means FMU of Batulanteh.

In our study, wild honey was shown to be a good option for providing additional income, in which one of the best wild honey in Indonesia (both in quantity and quality aspects). Forest area of Batulanteh can produce 15 ton year $^{-1}$ wild honey, mostly from protection forest area (FMU of Batulanteh 2012). Furthermore, Sumbawa honey contains more anti-bacteria and anti-oxidant than Sumatera and Kalimantan wild honey (Sholihah 2013) which useful for body healthy. The local communities who involved in wild honey business were still limited. Besides of wild honey, coffee and candle nut were also high commodities of local community. Unfortunately, the communities stated that they had no power to control the price of wild honey, coffee, candle nut but they were dependent on buyer competition for price decision. They sold raw honey, coffee, candle nut; they had no derived product to increase profit. Therefore, empowerment and cooperation in marketing and manufacturing of non-timber forest products is prospectively essential.

\section{Conservation agriculture}

Information regarding hydrological system is needed to determine activities in protection forest without reducing its main function. However the information of watershed and hydrological system in FMU of Batulanteh is still limited. The rainfall density is 746-2,556 $\mathrm{mm}^{-1}$ year $^{-1}$ and climate type is $\mathrm{D}$ and $\mathrm{E}$ based on Schmidt and Ferguson, and temperature is $24-32{ }^{\circ} \mathrm{C}$. Soil types in protection forest area are latisol, litosol and mediteran (FMU of Batulanteh 2012). Litosol soil has thin solum and high erodibility due to high erosion and it is available in steep areas. This soil is good for trees, cattle grass, and corn. Mediteran soil has intermediate until thick solum, intermediate erodibility, and low organic material (Rachim \& Arifin 2011).

In order to protect hydrological system and also stimulate community participation, FMU of Batulanteh needs to develop agriculture system which is applicable in protection forest area. Conservation agriculture is one of solution to meet ecology, social, and economic interest. Conservation agriculture is defined as agriculture system which has minimal soil disturbance and permanent soil cover combined with rotations. Conservation agriculture can improve agriculture through improvement in water infiltration and reducing erosion. It also helps reduce costs of production, saves time, increases yield through more timely 
planting (Hobbs 2007). Conservation agriculture can increase crop yield by $4.6 \%$ on average (Zheng et al. 2014).

FMU of Batulanteh and local community can make partnerships for coffee plantation and/or agricultural plantation by agroforestry system in degraded forest area. It refers to case in Lampung that successfully rehabilitated degraded land by establishment of coffee based agroforestry in state forest area (Suyanto et al. 2005). Based on field checking by FMU's staffs, critical protection forest was about 209 ha, rather critic was 1,216 ha, and potentially critics was 5,747 ha. Protection forest in good condition was about 5,344 ha (37\%). Coffee plantation in protection forest was 344 ha and degraded forest due to agricultural plantation has not identified yet. Agroforestry system in protection forest may be applied because it can maintain soil and conserve watershed, and its erosion rate is mutual in primary forests (Verbist et al. 2005; van Noordwijk et al. 2007). Furthermore, protection forest ecosystem will be stable in multi-species composition, prosperous natural regeneration, and optimal forest structure (Motta \& Haudemand 2000). Species composition needs to be suitable with its eco-region (Dorren et al. 2004). Therefore, agroforestry based good silvicultural techniques in protection forest will be no problem. As a note agroforestry systems should be implemented as a rehabilitation activity in degraded forests but not by cutting primary forests.

FMU of Batulanteh and local community need to determine agroforestry pattern to get highest benefits from an ecological, economical, and social perspective. Most farmers consider economical aspects more than biodiversity interests, such as observed in North Lampung (Wulandari et al. 2014). Furthermore, problem of protection forest in Sumbawa and Lampung are rather similar in case of illegal coffee plantation. Wulandari et al. (2014) stated that the highest net-present-value (NPV) of agroforestry pattern in North Lampung is rubber-coffee-wood plants-fruits. FMU of Batulanteh can adopt and modify this pattern based on Sumbawa condition, for example, by applying coffee-wood plant-food plant.

The best forest management is when it is closest to nature (Larsen 2015), thus planting indigenous species is more recommendable than non indigenous species. Based on field observation and literatures, several indigenous species of timber trees suitable to be planted in Sumbawa are Tetramales sp, Eugenia luminii, Arthocephalus cadamba, Duabanga moluccana. Wild bees (Apis dorsata) like to make honey nest in Tetramales sp., so it will be good for wild honey production. Meanwhile, E. luminii, A. cadamba, D. moluccana are fast growing species which can make various stratum of canopy easily and quickly. Food plants suitable to Sumbawa are corn, paddy, and Colocasia sp.. These species can grow well with D. moluccana (Surata 2007). Business of corn in Sumbawa also provides economic profit (Nurwahidah 2007).

\section{Illegal activities prevention}

In the partnership, FMU of Batulanteh can make agreement and requirement for community to ask their participation in maintaining and monitoring forest. Collaborative monitoring can build trust internally and credibility externally, share ecological understanding among diverse participants, foster social learning and communitybuilding, and advance adaptive management (FernandezGimenez et al. 2008). Community people have responsibility to conserve forest, so joint-responsibility of forest conservation is shared to all stakeholders who have partnership with FMU of Batulanteh. Punishments need to be declared clearly, in case community violates the agreement of partnership. On the other side, FMU of Batulanteh also needs to provide reward for community for their cooperativeness, such as helping nursery, marketing, and fertilizer for their agriculture activities. Therefore, reward-punishment system can be conducted to prevent illegal activities in protection forest. FMU of Batulanteh can also cooperate with academics, NGO, and/or other government agency to give environmental education for village youths to improve their environment awareness.

\section{Conclusion}

The knowledge of local communities on protection forest conservation was in average level, while their attitudes towards conservation were assessed as being on a higher level. The community empowerment program of FMU of Batulanteh had no significant influence on knowledge improvement, but it was effective for changing the community attitudes on protection forest conservation. Nonformal education such as training and forestry extension program is more influenced on knowledge and attitude than formal education, so community knowledge and attitudes can be improved through training and extension. Local communities had willing to conserve protection forest but they needed cash income for subsistence. Therefore, community empowerment program needed to be prioritized on economic aspects, conservation agriculture, and illegal activities prevention.

\section{References}

Agrawal A. 2003. Sustainable governance of common-pool resources: Context, methods, and politics. Annual Review of Anthropology 32:243-262. https://doi.org/10.1146/ annurev.anthro.32.061002.093112.

Ansong M, Roskaft E. 2011. Determinants of attitudes of primary stakeholders towards forest conservation management: A case study of Subri Forest Reserve, Ghana. International Journal of Biodiversity Science, Ecosystem Services and Management 7(2):98-107. https://doi.org/10.1080/21513732.2011.613411.

Arifudin, Nasrul B, Maswadi. 2013. Program of community empowerment prevents forest fires in Indonesia peat land. Procedia Environmental Science 17:129-134. https://doi.org/10.1016/j.proenv.2013.02.020.

Badola R, Barthwal S, Hussain SA. 2012. Attitudes of local communities towards conservation of mangrove forests: A case study from the east coast of India. Estuarine, Coastal and Shelf Science 96:188-196. https://doi.org/10.1016/ j.ecss.2011.11.016.

[BPS] Badan Pusat Statistik. 2016. Data dan Informasi Kemiskinan Kabupaten/Kota Tahun 2015. Jakarta: Badan 
Pusat Statistik.

Brockhaus M, Obidzinski K, Dermawan A, Laumonier Y, Luttrell C. 2012. An overview of forest and land allocation policies in Indonesia: Is the current framework sufficient to meet the needs of REDD+? Forest Policy and Economics 18:30-37. https://doi.org/10.1016/j.forpol.2011.09.004.

Budiono RP. 2006. The characteristic of farmer living around the Forest and the competency in protected forest sustainability in 12 villages at Lampung Province [dissertation]. Bogor: Bogor Agricultural University.

Colfer CJP. 2005. The Complex Forest: Communities, Uncertainty, and Adaptive Collaborative Management. Washington DC: Resources for the Future and Center for International Forestry Research.

Darusman D, Hardjanto, Suharjito D, Bahruni, Ichwandi I, Hero Y, Kartodihardjo H, Sudaryanto, Nugroho B, Nurrochmat DR, Sundawati L, Purwawangsa H, Trison S, Soedomo S. 2013. Membangkitkan kehutanan Indonesia: Kristalisasi konsep dan strategi implementasi. In: Suharjito D, Putro HR, editor. Bogor: Pembangunan Kehutanan Indonesia Baru: Refleksi dan Inovasi Pemikiran. IPB Press.

Dorren LKA, Berger F, Imeson AC, Maier B, Rey F. 2004. Integrity, stability and management of protection forests in the European Alps. Forest Ecology and Management 195:165-176. https://doi.org/10.1016/j.foreco.2004.02. 057.

Dunggio I. 2012. Model institution of protected forest management: Case management of Gunung Damar Forest Protected in Gorontalo Province [dissertation]. Bogor: Bogor Agricultural University.

$\mathrm{Du}$ Toit JT. 2012. Wildlife harvesting guidelines for community-based wildlife management: A southern African perspective. Biodiversity and Conservation 11:1403-1416. https://doi.org/10.1023/A:1016263606 704 .

Edmunds D, Wollenberg E. 2003. Local Forest Management: The Impacts of Devolution Policies. London: Earthscan.

Ekawati S. 2012. Analysis of policy making process and implementation of decentralized management of protected Forest Policy [dissertation]. Bogor Agricultural University, Bogor.

Ekawati S, Kartodihardjo H, Hardjanto, Dwiprabowo H, Nurrochmat DR. 2012. Policy making process of authorities among levels of government in the protected forest management and its implementation in the regency level. Jurnal Analisis Kebijakan Kehutanan 8(2):132-151. https://doi.org/10.20886/jakk.2011.8.2.132-151.

Evans K, de Jong W, Cronkleton P, Huu Nghi T. 2010. Participatory methods for planning the future in forest communities. Society and Natural Resources 23:604-619. https://doi.org/10.1080/08941920802713572.

Evans K, Velarde SJ, Prieto RP, Rao SN, Sertzen S, Davila K, Cronkleton P, de Jong W. 2006. Field Guide to the Future: Four Ways for Communities to Think Ahead. Bennett E, Zurek M, editor. Nairobi: Center for International Forestry Research, ASB, World Agroforestry Centre.

Fernandez-Gimenez ME, Ballard HL, Sturtevant VE. 2008. Adaptive management and social learning in collaborative and community-based monitoring: a study of five community-based forestry organizations in the western USA. Ecology and Society 13(2):4. https://doi.org/10. 5751/ES-02400-130204.

FMU of Batulanteh. 2012. Rencana Pengelolaan KPHP Batulanteh Tahun 2012-2022. Sumbawa: FMU of Batulanteh.

[FWI] Forest Watch Indonesia. 2014. Potret Keadaan Indonesia Periode 2009-2013. Bogor: Forest Watch Indonesia.

Ginoga K, Lugina M, Djaenudin D. 2005. Policy analysis of protection forest management. Jurnal Penelitian Sosial dan Ekonomi 2(2):203-231.

Mutaqin Z. 2014. Kelembagaan Pengelolaan Hutan Berbasis Masyarakat dan Kaitannya dengan Implementasi $R E D D+$ di Indonesia. In: Hutan untuk Rakyat: Jalan Terjal Reforma Agraria di Sektor Kehutanan. Hakim I, Wibowo LR, editors. Yogyakarta: LKiS Yogyakarta, Pusat Penelitian dan Pengembangan Perubahan Iklim dan Kebijakan.

Hobbs PR. 2007. Conservation agriculture: what is it and why is it important for future sustainable food production? The Journal of Agricultural Science 145(2):127-137. https://doi.org/10.1017/S0021859607006892.

Hoch L, Pokorny B, de Jong W. 2009. How successful is tree growing for smallholders in the Amazon? International Forestry Review 11: 299-310. https://doi.org/10. 1505/ifor.11.3.299.

Infield M, Namara A. 2001. Community attitudes and behaviour towards conservation:an assessment of a community conservation programme around Lake Mburo National Park, Uganda. Oryx 35:48-60. https://doi.org/10.1017/S0030605300031537.

Larsen JB. 2015. Close-to-nature forest management: the Danish approach to sustainable forestry. In: Hapke A, editor. Advanced Sustainable Forest Management. New York: Callisto Reference.

Motta R, Haudemand JC. 2000. Protective forests and silvicultural stability: An example of planning in the Aosta valley. Mountain Research and Development 20:74-81. https://doi.org/10.1659/0276-4741(2000)020[0180: PFASS]2.0.CO;2. 
Nurwahidah S. 2014. Analisis komparatif usahatani jagung lahan sawah dan lahan kering di Kabupaten Sumbawa. Agritech 16(2):118-128.

Ostrom E. 1999. Self Governance and Forest Resources. Bogor: Center for International Forestry Research. https://doi.org/10.17528/cifor/000536.

Perkins DD, Zimmerman MA. 1995. Empowerment theory, research, and application. American Journal of Community Psychology 23(5):569-579. https://doi.org/10. 1007/BF02506982.

Purnomo H, Mendoza GA, Prabhu R, Yasmi Y. 2005. Developing multi-stakeholder forest management scenarios: A multi-agent system simulation approach applied in Indonesia. Forest Policy and Economics 7: 475-491. https://doi.org/10.1016/j.forpol.2003.08.004.

[Pusrenbang] Pusat Perencanaan dan Pengembangan Sumber Daya Manusia. 2015. Laporan Penyusunan Struktur Organisasi dan Pengembangan Sumber Daya Manusia KPHP Batulanteh Provinsi Nusa Tenggara Barat. Jakarta: Kementerian Lingkungan Hidup dan Kehutanan.

Rachim DA, Arifin M. 2011. Klasifikasi Tanah di Indonesia. Nadeak W, editor. Bandung: Pustaka Reka Cipta.

Rappaport J. 1984. Studies in empowerment: Introduction to the issue. Prevention in Human Services 3:1-7. https://doi.org/10.1300/J293v03n02_02.

Ratsimbazafy CL, Harada K, Yamamura M. 2012. Forest resource use, attitude, and perception of local residents towards community based forest management: Case of the Makira Reducing Emissions from Deforestation and Forest Degradation (REDD) Project, Madagascar. Journal of Ecology and the Natural Environment 4(13):321-332. https://doi.org/10.5897/JENE11.123.

Setiajiati F. 2017. Desain model pengelolaan hutan lindung di KPHP Batulanteh, Provinsi Nusa Tenggara Barat [thesis]. Bogor: Institut Pertanian Bogor.

Sholihah J. 2013. Antibacterial and antioxidant activity of three types Indonesian forest honey [undergraduate thesis]. Bogor: Bogor Agricultural University.

Schusser C. 2013. Who determines biodiversity? An analysis of actors' power and interests in community forestry in Namibia. Forest Policy and Economics 36:42-51. https://doi.org/10.1016/j.forpol.2012.06.005.

Sukardi L, Darusman D, Sundawati L, Hardjanto. 2008. Characteristics and main factors affecting interaction between local community and Rinjani Mountain National Park on Lombok Island. Agroteksos 18(1-3):54-62.

Supardi D, Muin F, Herawati, Jumiati. Kartini N, Kholis N, Nurdayat M. 2006. Pembebasan Hak yang Tersandera: Pergulatan Pengelolaan Sumber Daya Hutan Sumbawa. Yogyakarta: BPArupa.

Surata IK. 2007. Plantation trial of duabanga (Duabanga moluccana Blume) on intercropping system at Rarung, West Nusa Tenggara Province. Jurnal Penelitian Hutan dan Konservasi Alam 4(4):365-376.

Suyanto S, Permana RP, Khususiyah N, Joshi L. 2005. Land tenure, agroforestry adoption, and reduction of fire hazard in a forest zone: a case study from Lampung, Sumatra, Indonesia. Agroforestry System 65:1-11. https://doi.org/ 10.1007/s10457-004-1413-1.

Triguero-Mas M, Olomi-Sola M, Jha N, Zorondo-Rodriguez F, Reyes-Garcia V. 2010. Urban and rural perceptions of protected areas: a case study in Dandeli Wildlife Sanctuary, Western Ghats, India. Environmental Conservation 36(3):208-217. https://doi.org/10.1017/ S0376892909990403.

Van Noordwijk M, Leimona B, Emerton L, Tomich TP, Velarde SJ, Kallesoe M, Sekher M, Swallow B. 2007. Criteria and indicators for environmental service compensation and reward mechanisms: realistic, voluntary, conditional and pro-poor. Nairobi: World Agroforestry Centre.

Verbist B, Eka DA, Budidarsono S. 2005. Factors driving land use change: effects on watershed functions in a coffee agroforestry system in Lampung, Sumatra. Agricultural System 85:254-270. https://doi.org/10.1016/j.agsy.2005. 06.010 .

Wollenberg E, Belcher B, Sheil D, Dewi S, Moeliono M. 2004. Why are Forest Area Relevant to Reducing Poverty in Indonesia? Bogor: CIFOR.

Wulandari C, Budiono P, Yuwono SB, Herwanti S. 2014. Adoption of agro-forestry patterns and crop systems around Register 19 Forest Park, Lampung Province, Indonesia. Jurnal Manajemen Hutan Tropika 20(2): 86-93. https://doi.org/10.7226/jtfm.20.2.86

Zheng C, Jiang Y, Chen C, Sun Y, Feng J, Deng A, Song Z, Zhang W. 2014. The impacts of conservation agriculture on crop yield in China depend on specific practices, crops and cropping regions. The Crop Journal 2: 289-296. https://dx.doi.org/10.1016/j.cj.2014.06.006. 